\title{
A 435-YEAR-LONG EUROPEAN BLACK PINE (PINUS NIGRA) CHRONOLOGY FOR THE CENTRAL-WESTERN BALKAN REGION
}

\author{
S. POLJANŠEK ${ }^{1}$, D. BALLIAN ${ }^{2}$, T. A. NAGEL ${ }^{3}$, and T. LEVANIČ ${ }^{1 *}$ \\ ${ }^{1}$ Slovenian Forestry Institute, Večna pot 2, SI-1000 Ljubljana, Slovenia \\ ${ }^{2}$ University of Sarajevo, Faculty of Forestry, Zagrebačka 20, 71000 Sarajevo, Bosnia and Herzegovina \\ ${ }^{3}$ Biotechnical faculty, Department of Forestry, Večna pot 83, SI-1000 Ljubljana, Slovenia
}

\begin{abstract}
We describe the development of the first black pine (Pinus nigra Arnold) regional chronology for the central-western Balkan area, Bosnia and Herzegovina $(\mathrm{BiH})$, based on seven site chronologies from different parts of the country. Pointer-year analysis identified a common signal (possibly climate) in the site chronologies - at least five positive $(1876,1930,1941,1969)$ and nine negative pointer years $(1874,1880,1891,1931,1943,1963,1971,1987,2000)$ are common to all seven study sites. Site chronologies were compared using statistical parameters and visual crossdating, from which we constructed a 435-year-long tree-ring width chronology for $P$. nigra for $\mathrm{BiH}$ and compared it with existing P. nigra chronologies from Montenegro, Greece, Albania, Austria (Vienna region), and France (Corsica). The resulting statistical and visual similarity indicated that the chronology has a strong regional signal and therefore can be included in the dendrochronological network for $P$. nigra for the Western Balkans.
\end{abstract}

Keywords: Pinus nigra, climate change, Bosnia and Herzegovina, dendroclimatology, dendrochronology.

\section{INTRODUCTION}

Dendrochronological research has a long tradition in the western and central part of the Mediterranean, such as Spain, France, Italy, Morocco, Tunisia, and Algeria (Martinelli 2004). However, the eastern part of the Mediterranean region had been largely overlooked until 1999 (Touchan and Hughes 1999), after which this situation improved as dendrochronological studies started to emerge in Jordan, Syria, Cyprus, Lebanon, and Turkey (Touchan et al. 2005b; Sevgi and Akkemik 2007; Touchan et al. 2007; Touchan et al. 2008). Currently, long chronologies for different tree species are available, as well as long-term reconstructions of different climatic parameters (see Touchan et al. 2007). Other studies have also realized the importance of the lack of data in the eastern region of the Mediterranean. Allen et al. (2010) clearly identify

*Corresponding author: tom.levanic@gozdis.si that data are needed on tree growth, climategrowth, as well as climate-mortality relationships.

In Bulgaria and Romania dendrochronological research is progressing. Panayotov et al. (2010) compiled a 758-year-long chronology for Pinus heldreichii Christ. and a 340-year-long chronology for Pinus peuce Gris., while Popa and Kern (2009) developed a 1,000-year-long chronology of Pinus cembra L. for Romania and reconstructed summer mean temperature anomalies for the period AD 1163-2005. In Austria, Strumia et al. (1997) studied the response of black pine (Pinus nigra Arn.) to precipitation and reported a high sensitivity to summer rainfall, whereas Leal et al. (2008) observed a decreasing sensitivity of the response to spring-summer precipitation towards the end of the 20th Century.

Dendrochronological work in Greece, $\mathrm{Cy}$ prus and in countries of the Near East (Turkey, Syria, Lebanon) is also well developed (Kuniholm and Striker 1983; Touchan et al. 2005a). At this stage, new chronologies have been constructed 
and the first regional reconstructions of climate parameters have been published, including a long regional oak tree-ring width chronology (Kuniholm and Striker (1983) as well as the reconstruction of spring-summer precipitation for the Eastern Mediterranean (Touchan et al. 2005b) and a study of the association between signature years and the seasonal patterns of atmospheric circulation (Hughes et al. 2001).

Dendrochronological work in Albania, unlike that in Greece and the Near East, is being slowly developed by research teams from various countries. The first chronology of $P$. nigra from Albania and its response to climate was published by Levanič and Toromani (2010), while Seim et al. (2010) constructed a 1,000-year-long tree-ring width and tree-ring density chronology for $P$. heldreichiii in Albania.

In contrast to the rapid and systematic development of dendrochronological networks all around the Mediterranean basin, the Western Balkan region, which includes Montenegro, Bosnia and Herzegovina $(\mathrm{BiH})$ and Croatia, has been less intensively investigated by dendrochronologists, and systematic dendrochronological work focusing on chronology development and climatetree growth relationships, or addressing different dendroecological questions, has been largely absent. We are aware of two dendroecological studies by Accetto (1979) on the growth dynamics and natural regeneration of $P$. nigra and $P$. heldreichii in Central $\mathrm{BiH}$. That study was limited to a relatively small area and focused more on stand dynamics than on the development of long chronologies. There are only a few chronologies from this region in the International Tree-ring Data Bank - P. nigra chronologies from Ravno Borje (Kuniholm 1981) and Picea abies chronologies from Jahorina, Čakor and Vlasić (Schweingruber 1996a). Although Kuniholm and Striker (1983) built a network of more than 50 Greek and Turkish sites, only one chronology from Duboka, Serbia, originates from the region we studied.

The Balkan Peninsula in Southeastern Europe is $c a$. $550,000 \mathrm{~km}^{2}$ in size. It has a strong north-south temperature gradient, which can be viewed as a climatic transition from the strong Mediterranean conditions in Greece to temperate conditions toward the Alps, as well as a strong east-west precipitation gradient, resulting in a diverse climate throughout the region. Forests in this region are diverse, and forest communities on southern slopes, shallow soils and limestone bedrock in the Mediterranean climate zone of the western part of the Peninsula are especially susceptible to the predicted increase in temperature and decrease of precipitation (Pachauri and Reisinger 2007). For these reasons, the Balkan Peninsula is an important region for dendrochronological and dendroclimatological work, which has been exploited in its eastern, but not in its western part. We therefore decided to initiate systematic dendrochronological work on $P$. nigra in the western part of the Balkan Peninsula. $P$. nigra grows on extreme sites, has a wide ecological amplitude and distribution range, and responds well to environmental changes (see Fritts 1976). Its natural range of distribution extends from the vicinity of Vienna, Austria, in the north to Greece in the south, and covers all western Balkan countries. $P$. nigra can grow on different substrates and bedrock, such as limestone, dolomite, and serpentine-peridotite (Vidaković 1991; Isajev et al. 2004). Our study had the following goals:

- construction of tree-ring width chronologies for P. nigra on many natural sites in Bosnia and Herzegovina,

- development of a regional P. nigra chronology for Bosnia and Herzegovina,

- comparison of pointer years between sites and between neighboring countries,

- connection of the newly developed $P$. nigra chronology with other $P$. nigra chronologies from the Balkan Peninsula and neighboring countries.

\section{MATERIALS AND METHODS}

\section{Sampling Locations}

Seven $P$. nigra sites were sampled in $\mathrm{BiH}$. They ranged in elevation from $500 \mathrm{~m}$ to $1,500 \mathrm{~m}$ a.s.1., with a southern aspect at higher elevations and a northern aspect at lower elevations (Table 1, Figure 1). Apart from the other six sites, trees at Šipovo (SIP) were sampled on the northern and 
Table 1. Basic characteristics of the P. nigra sampling locations in Bosnia and Herzegovina.

\begin{tabular}{llrrrrll}
\hline \multicolumn{1}{c}{ Site } & Code & Latitude N & Longitude E & Elevation $[\mathrm{m}]$ & Slope $\left[^{\circ}\right]$ & Aspect & Bedrock \\
\hline Blace & BLA & $43^{\circ} 31^{\prime}$ & $18^{\circ} 07^{\prime}$ & 950 & 50 & SE & Dolomite \\
Konjuh & KON & $44^{\circ} 17^{\prime}$ & $18^{\circ} 32^{\prime}$ & 1,100 & 45 & $\mathrm{~S}$ & Serpentine \\
Krivaja & KRI & $44^{\circ} 13^{\prime}$ & $18^{\circ} 29^{\prime}$ & 500 & 60 & NE & Serpentine \\
Perućica & PER & $43^{\circ} 19^{\prime}$ & $18^{\circ} 42^{\prime}$ & 1,450 & 55 & $\mathrm{~S}$ & Limestone \\
Prusačka rijeka & PRU & $44^{\circ} 04^{\prime}$ & $17^{\circ} 21^{\prime}$ & 1,100 & 65 & $\mathrm{~S}$ & Limestone \\
Šator & SAT & $44^{\circ} 11^{\prime}$ & $16^{\circ} 36^{\prime}$ & 1,300 & 55 & $\mathrm{~S}$ & Dolomite \\
Šipovo & SIP & $44^{\circ} 17^{\prime}$ & $17^{\circ} 12^{\prime}$ & 1,100 & 60 & $\mathrm{~S} \& \mathrm{~N}$ & Limestone \\
\hline
\end{tabular}

southern side of the slopes above the gorge. All study sites had a low stand density, so the sampled trees had plenty of growing space and no betweentree competition. Many sampled trees were growing on a ridge (see Figure 2). All study sites were more or less pure $P$. nigra stands with only a minor occurrence of other tree species (e.g.
Fraxinus ornus L., Pinus sylvestris L., Quercus petraea Liebl., and Quercus pubescens Wild.). According to local foresters, some locations have had frequent forest fires (also visible as fire scars on the stem) caused by lightning, and some sites have been heavily affected by intensive resin collection (such trees were not sampled). The

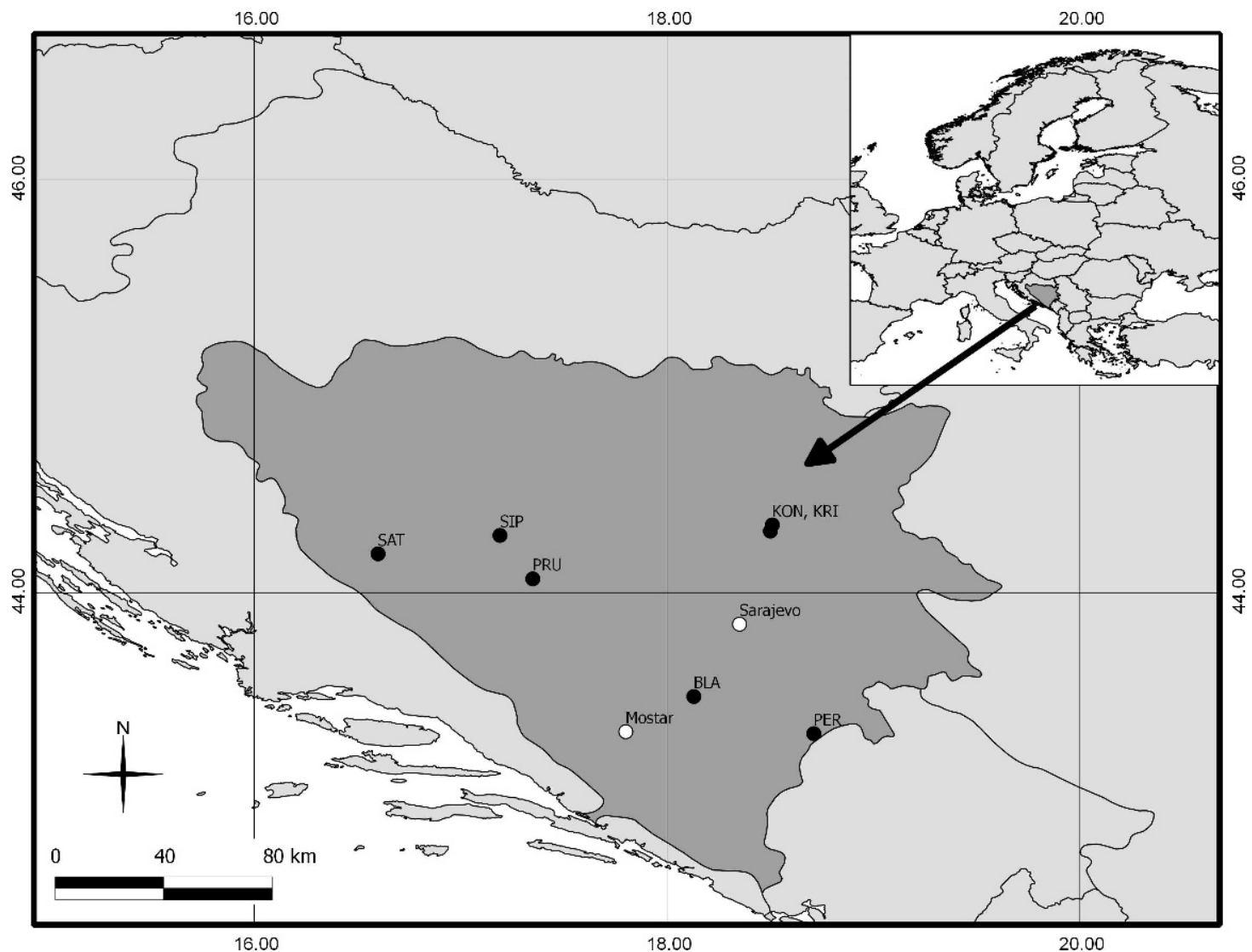

Figure 1. Sampling sites $(\bullet)$ of P. nigra in Bosnia and Herzegovina (dark gray area); Blace (BLA), Konjuh (KON), Krivaja (KRI), Perućica (PER), Prusačka rijeka (PRU), Šator (SAT) and Šipovo (SIP); meteorological stations (O) Mostar and Sarajevo. 


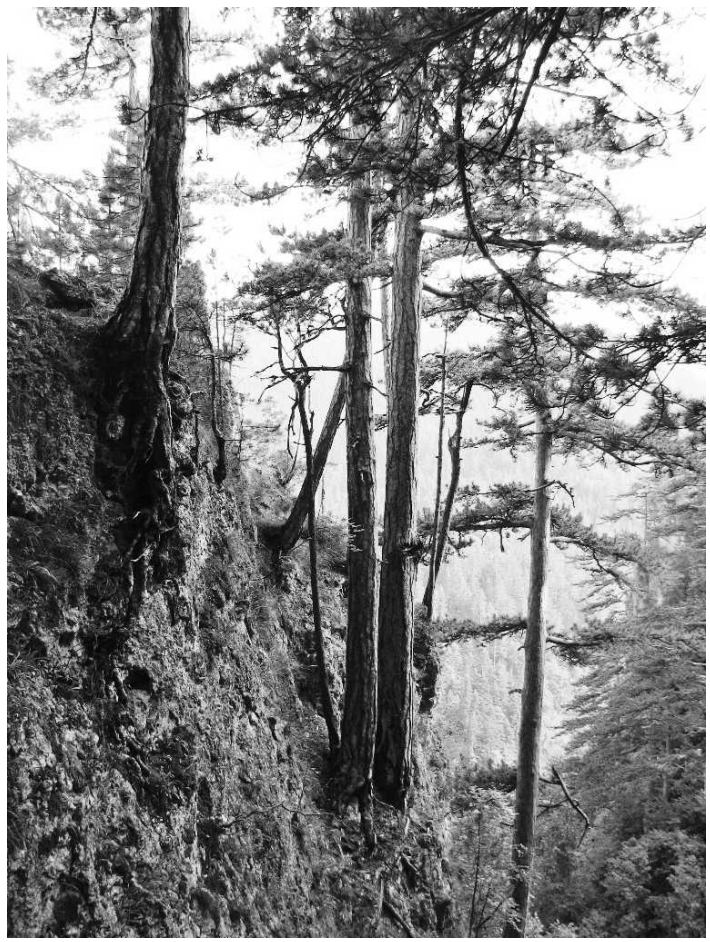

Figure 2. Typical site with $P$. nigra growing on a steep limestone slope of the Prusac gorge, Bosnia and Herzegovina (photo: Simon Poljanšek).

sampling locations were evenly distributed across $\mathrm{BiH}$ and covered the majority of the sites where $P$. nigra is found in natural stands (Figure 1).

\section{Main Characteristics of Black Pine (Pinus nigra Arn.)}

P. nigra is a widespread species on the Balkan Peninsula. It can be found in a wide altitudinal range, from 500 to $2,000 \mathrm{~m}$ a.s.l. and can measure as much as $50 \mathrm{~m}$ in height and over $1 \mathrm{~m}$ in diameter. On some extreme sites it can reach over 500 years of age (Brus 2004). It has distinct annual rings with clearly visible earlywood and latewood. Resin ducts are abundant and mainly in the latewood, and missing or false rings can occur, especially on extreme sites. P. nigra is not shadetolerant, but can resist low winter and high summer temperatures. Its thick bark makes it more fire resistant than other tree species in the area. All $P$. nigra subspecies are mountain species that occupy intermediate plains and more or less steep slopes of the wider Mediterranean region. In low elevations of the Mediterranean part of its distribution, natural $P$. nigra stands are found on north-facing slopes, whereas in alpine and continental areas, they are located on south-facing slopes (Bussotti 2002). P. nigra is well adapted to extreme sites with summer heat and a lack of precipitation. It can grow on steep, rocky slopes where soils are highly erodible and on dolomite, limestone, or serpentine-peridotite bedrock where growth conditions for other tree species are too extreme. Sites on serpentine-peridotite are particularly interesting as this bedrock type is characterized by low fertility, low soil moisture, calcium deficiency, high concentrations of heavy metals, and low plant nutrients. Serpentine-peridotite substrate varies from $\mathrm{pH}$ 5.5-8 (Proctor and Woodell 1975; Stevanović et al. 2003). Because trees on these sites grow slowly, we can expect to find very old individuals. Such trees are highly suitable for the development of long chronologies or investigation of climatological and ecological questions related to tree growth (Leal et al. 2008; Linares and Tíscar 2010).

\section{Sampled Trees}

Old, dominant or co-dominant trees with a healthy trunk and no signs of resin exploitation were selected for sampling. From each tree, two cores from opposite sides were taken at breast height $(1.3 \mathrm{~m})$ and perpendicular to the slope to avoid compression wood. On extreme terrain, we took only one core per tree, or the core was taken at a greater height than normal (i.e. 1.5-2 m). Cores were air-dried and glued on wooden holders, and sanded with progressively finer sandpaper until a high-polish surface was achieved (Stokes and Smiley 1996). Samples were scanned using the ATRICS system (Levanič 2007) and measured using WinDENDRO software (www. regentinstruments.com). The width of each annual ring was measured to the nearest $0.01 \mathrm{~mm}$.

\section{Climate}

Geographically, the Balkan Peninsula represents an important north-south transect and a 


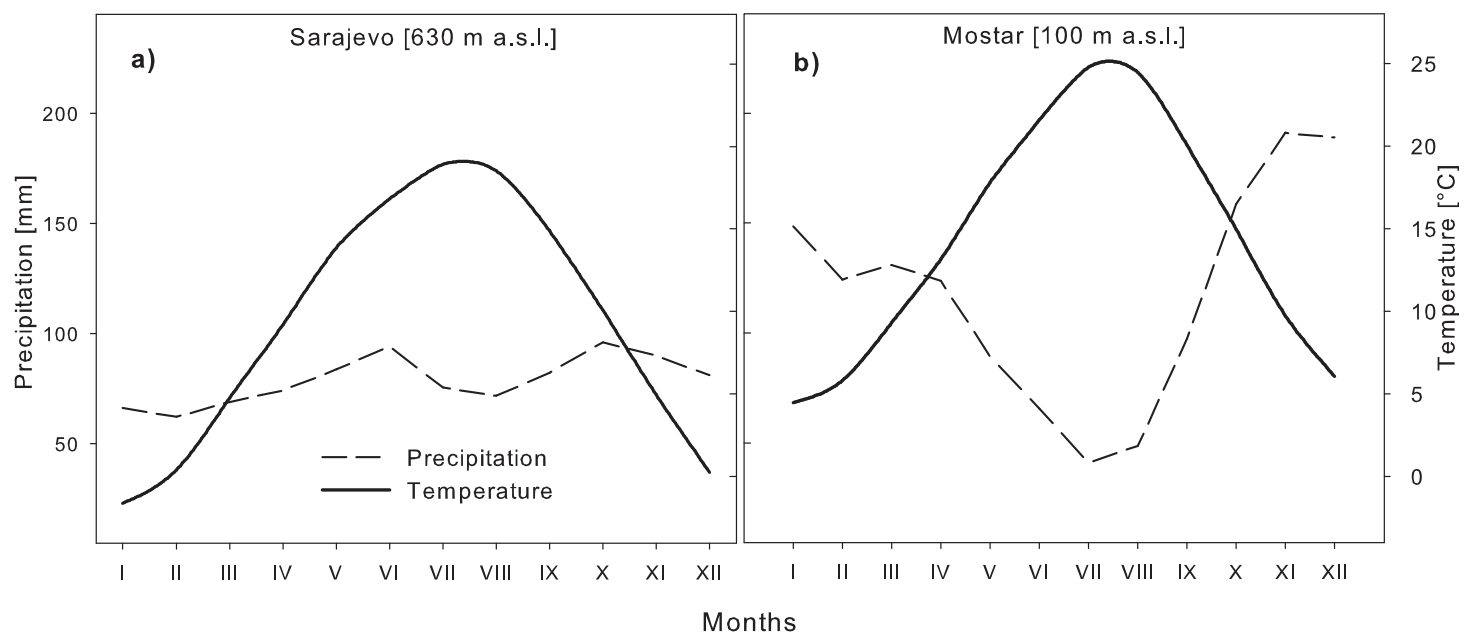

Figure 3. Climate diagram based on the HISTALP dataset (Auer et al. 2007) for the period 1881-2006 for (a) Sarajevo and (b) Mostar.

climatic transition zone between the Mediterranean and Central European synoptic - temperate zone (Eastwood 2004). Although the vegetation in $\mathrm{BiH}$ belongs to the Mediterranean vegetation community (Eastwood 2004), it is enriched by diverse geographical features. This leads to high species diversity and makes $\mathrm{BiH}$ one of Europe's biodiversity hotspots (Gibson et al. 2003).

$\mathrm{BiH}$ is located in the northwestern part of the Balkan Peninsula, between $42^{\circ} 26^{\prime}$ to $45^{\circ} 15^{\prime} \mathrm{N}$ and $15^{\circ} 44^{\prime}$ to $19^{\circ} 41^{\prime} \mathrm{E}$. It is bordered by Croatia to the north, west, and south, by Serbia to the east, and by Montenegro to the southeast. Because of its geographical position, proximity to the Adriatic Sea, and distinct topography, the northern part of the country has a moderate continental climate with July temperature around $20^{\circ} \mathrm{C}$ and 700 $800 \mathrm{~mm}$ of annual precipitation (Pintarić 1999). In the central mountainous area severe winters with abundant snowfall prevail. Warm humid air from the Adriatic Sea often collides with cooler air above the Dinaric Alps, and as a consequence, the Čvrsnica (2,000 m a.s.1.), Prenj (1,900 m a.s.1.) and Džamija (1,800 m a.s.1.) mountain peaks receive abundant precipitation - annual precipitation on these peaks averages from 3,000-5,000 mm, among the highest recorded in Europe. Bjelašnica (2,000 $\mathrm{m}$ a.s.1.), located behind the first range, still receives more than $1,800 \mathrm{~mm}$ of yearly precipitation, although there can be large differences between years, with a maximum of $3,157 \mathrm{~mm}$ in 1900 and a minimum of $627 \mathrm{~mm}$ in 1954 (Federal Hydrometeorological Institute of Bosnia and Herzegovina).

Mountain ranges in $\mathrm{BiH}$ have an important impact on climate. They reduce the influence of the Mediterranean and enhance the influence of the continental climate over a very short distance. Western $\mathrm{BiH}$ has a typical sub-Mediterranean climate pattern with warm and wet late autumn and winter months $\left(6.5^{\circ} \mathrm{C}\right.$ average winter temperature and $650 \mathrm{~mm}$ precipitation) and hot and dry summers $\left(22^{\circ} \mathrm{C}\right.$ and $250 \mathrm{~mm}$ precipitation). As there are three types of climate that influence the $\mathrm{BiH}$ area, a mixed climatic influence is observed in weather station data that are provided by the HISTALP climate database project (Auer et al. 2007). The variability of climate in $\mathrm{BiH}$ is wellrepresented by two meteorological stationsMostar and Sarajevo. The Mostar meteorological station (Figure 3b) represents a typical sub-Mediterranean climate - the temperature is high in July-August $\left(25^{\circ} \mathrm{C}\right.$ average monthly temperature) and precipitation is most abundant from October to January $(700 \mathrm{~mm})$. Winter is not particularly cold $\left(6^{\circ} \mathrm{C}\right)$ and summer is very dry $(245 \mathrm{~mm}$ from May-August). The climate of the inner part of $\mathrm{BiH}$ is well-represented by the meteorological station in Sarajevo (Figure 3a); it is a moderate continental climate-mountain ridges oriented north-south 
prevent the Mediterranean climate from reaching deep into the country, which results in cool summers $\left(17^{\circ} \mathrm{C}\right.$ average monthly temperature) and equally distributed precipitation over the year (1,000 $\mathrm{mm}$ of annual precipitation).

\section{Statistical Methods}

Crossdating of chronologies was done with PAST $-4^{\text {TM }}$ software (www.sciem.com) using both visual on-screen comparisons and statistical parameters, such as the t-value after Baillie and Pilcher $\left(t_{B P}\right)(1973)$ and Gleichläufigkeits coefficient (GLK\%) (Eckstein and Bauch 1969). False and missing rings were counted across all tree-ring series per site and summed. Additionally, quality control using program COFECHA was applied to check for measurement errors (Holmes 1983). If necessary, measurements were repeated, rechecked, or removed from further processing if recognized as unusable. Reasons why certain trees were removed from the sample pool were growth anomalies connected with historical resin collection, overgrown wounds, or occurrence of compression wood deep inside the trunk. In three cases we were not able to measure tree-ring widths on the entire core, just on their older sections. This caused a small decrease in sample depth after 1900. Because the sample depth in the last 100 years is more than adequate, we are confident that this did not influence the overall results.

Individual tree-ring width (TRW) series were standardized to remove long-term trends (Cook 1985), and all basic statistical parameters of TRW were calculated using ARSTAN for Windows (Cook and Holmes 1999). Each series of tree-ring widths was fit with a cubic smoothing spline with a $50 \%$ frequency response at $67 \%$ of the series length to remove non-climatic trends related to age, size, and the effects of stand dynamics (Cook and Briffa 1990). Each year's ring width was divided by the year's value of the fitted curve to give a dimensionless index with a mean of one. Index values were then prewhitened using an autoregressive model selected on the basis of the minimum Akaike criterion and combined across all series using biweight robust estimation of the mean to exclude the influence of outliers. Two chronologies were produced this way - a standard chronology and a residual chronology containing only high-frequency variations with statistically removed autocorrelation (Cook 1985; Cook et al. 1990).

The regional chronology was calculated in ARSTAN using the same parameters as for the site chronologies. The main difference between the site chronologies and the regional chronology is that we first composed a file containing all individual raw TRW series and then ran ARSTAN to produce a standard and residual regional chronology.

Signal strength in site chronologies was tested using Expressed Population Signal - EPS (Wigley et al. 1984; Briffa and Jones 1990). Calculation of EPS is based on a 50-year moving window with a 25 year overlap. For each window, ARSTAN calculates the average between-tree correlation, number of trees included, and EPS. We also calculated the usable portions of the chronologies to ensure the reliability of any future climate reconstructions that may be carried out with this dataset. The usable portion of a chronology was defined as the part where a minimum number of trees maintains an EPS value above 0.85 (Briffa and Jones 1990).

Pointer years (PYs) were calculated for each site and compared between sites to search for a common forcing in the tree-ring widths. According to Schweingruber et al. (1990), PYs are defined as years when at least $80 \%$ of 13 trees respond with an increase or decrease in tree-ring width. An exception was made for sites KRI and PRU where, because of the small number of accepted samples, conditions for PYs were set at $90 \%$ of 10 trees for KRI and $83 \%$ of 12 trees for BLA. PYs were calculated with non-standardized tree-ring series. We also identified "Regional" PYs, defined as pointer years that were common on at least four out of seven site chronologies. Finally, the results of the PY analysis were compared with PYs calculated from various tree species in $\mathrm{BiH}$, Greece, Italy, Turkey, and Serbia in a study by Hughes et al. (2001).

\section{RESULTS}

\section{Construction of Site Chronologies}

Seven P. nigra site chronologies of different length between 198 and 430 years were built for 
Table 2. Basic data of the site chronologies.

\begin{tabular}{|c|c|c|c|c|c|c|c|c|c|c|}
\hline Site & Time Span & Length & Trees & Cores & $\begin{array}{c}\text { Trees } \\
\text { Excluded }\end{array}$ & $\begin{array}{l}\text { False } \\
\text { Rings }\end{array}$ & $\begin{array}{c}\text { Missing } \\
\text { Rings }\end{array}$ & $\begin{array}{c}\text { Average } \\
t_{\mathrm{BP}}\end{array}$ & $\begin{array}{c}\text { Min-Max } \\
t_{B P}\end{array}$ & $\begin{array}{l}\text { Average } \\
\text { GLK\% }\end{array}$ \\
\hline BLA & $1625-2010$ & 386 & 21 & 41 & 9 & 0 & 2 & 13.5 & $10.5-16.9$ & 73.1 \\
\hline $\mathrm{KON}$ & $1626-2010$ & 385 & 24 & 45 & 6 & 0 & 31 & 17.8 & $13.5-23.9$ & 74.8 \\
\hline KRI & $1667-2010$ & 344 & 18 & 29 & 8 & 7 & 7 & 14.6 & $10.8-17.1$ & 73.1 \\
\hline PER & $1603-2010$ & 408 & 33 & 50 & 9 & 3 & 7 & 13.9 & $8.93-20.1$ & 71.3 \\
\hline PRU & 1694-2010 & 317 & 15 & 22 & 5 & 0 & 15 & 12.1 & $8.63-13.8$ & 63.3 \\
\hline SAT & 1813-2010 & 198 & 20 & 40 & 4 & 3 & 16 & 13.0 & $10.4-17.2$ & 73.3 \\
\hline SIP & $1576-2005$ & 430 & 35 & 58 & 12 & 4 & 19 & 11.4 & $8.47-15.8$ & 68.1 \\
\hline
\end{tabular}

Bosnia and Herzegovina (Table 2). On each site we found trees that could not be crossdated with others; such trees were removed from the data pool. The highest number of excluded trees was at SIP (12 out of $35 ; 34 \%$ ); however, the highest proportion of trees excluded was at KRI ( 8 out of 18; 44\%). Because trees at KRI were used for the industrial exploitation of resin, only 18 trees were found without visible damage to the trunk, and only 10 could be crossdated. A similar problem occurred at PRU, where, because of the extremely steep slope, only 15 trees could be sampled and just 10 of them crossdated (Table 2).

In some trees, false rings and missing rings were detected. Missing rings were identified in cases where one core had a ring in a certain year and the core from the opposite side did not. For example, at BLA we collected 41 cores and found just two missing rings (Table 2). Seven missing and false rings were identified at KRI. The largest number of missing rings was found at KON (31 altogether). Trees within sites crossdated very well, as values of coefficients $t_{\mathrm{BP}}$ and GLK\% were high at all locations (Table 2). The highest maximum (23.9) and average values (17.8) of $t_{\mathrm{BP}}$ were found at $\mathrm{KON}$, and the lowest values were found at SIP (15.8 and 11.4, respectively).

In general, all tree rings were narrow (mean value below $1 \mathrm{~mm}$ ). The widest TRW was found at PRU (4.29 $\mathrm{mm})$ and the narrowest at KRI $(0.11 \mathrm{~mm})$ (Table 3$)$. The lowest standard deviation was found at SIP (0.25) and the highest at SAT (0.66). The highest values of mean sensitivity were at BLA, KRI, PER, and SAT, while KON, PRU, and SIP had values below 0.20. Values of the first-order autocorrelation in the raw chronologies were high, meaning that growth conditions in the previous year influence tree-ring width in the current year. Autocorrelation in the standardized chronologies were slightly lower than in the raw chronologies and completely negligible in the residual chronologies.

Table 3. Tree-ring width (TRW) statistics for raw chronologies, including mean, standard deviation (st. dev.), minimum and maximum tree-ring width, mean segment length, expressed population signal (EPS), mean sensitivity (MS), as well as first-order autocorrelation ac(1) for the raw, standard, and residual chronologies.

\begin{tabular}{|c|c|c|c|c|c|c|c|c|c|c|}
\hline \multirow[b]{2}{*}{ Site } & \multicolumn{7}{|c|}{ Raw Chronology } & \multicolumn{3}{|c|}{$\operatorname{ac}(1)$} \\
\hline & Mean & St. dev. & Min-Max & $\mathrm{mssl}^{*}$ & $\mathrm{EPS}>0.85$ & MS & $\mathrm{r}_{\mathrm{BT}^{* *}}$ & RAW & STD & RES \\
\hline BLA & 0.77 & 0.29 & $0.16-2.30$ & 263 & 1830 & 0.22 & 0.39 & 0.73 & 0.68 & 0.00 \\
\hline $\mathrm{KON}$ & 0.74 & 0.43 & $0.21-3.52$ & 330 & 1705 & 0.19 & 0.48 & 0.87 & 0.74 & 0.00 \\
\hline KRI & 0.70 & 0.47 & $0.11-3.33$ & 280 & 1745 & 0.24 & 0.46 & 0.84 & 0.49 & 0.03 \\
\hline PER & 0.98 & 0.42 & $0.25-2.30$ & 291 & 1660 & 0.23 & 0.39 & 0.84 & 0.65 & 0.00 \\
\hline PRU & 0.99 & 0.49 & $0.29-4.29$ & 277 & 1825 & 0.17 & 0.37 & 0.85 & 0.57 & -0.01 \\
\hline SAT & 1.44 & 0.66 & $0.23-3.33$ & 165 & 1870 & 0.23 & 0.43 & 0.88 & 0.57 & -0.00 \\
\hline SIP & 0.75 & 0.25 & $0.20-0.87$ & 292 & 1730 & 0.15 & 0.29 & 0.81 & 0.67 & 0.01 \\
\hline
\end{tabular}

*Mean sample segment length.

**Correlation among trees $\left(\mathrm{r}_{\mathrm{BT}}\right)$ calculated with residual tree-ring series. 
Table 4. Comparison of $t_{B P}$ (upper triangular of matrix) and GLK\% (lower triangular of matrix) coefficients between site chronologies.

\begin{tabular}{|c|c|c|c|c|c|c|c|}
\hline Site & BLA & $\mathrm{KON}$ & KRI & PER & PRU & SAT & SIP \\
\hline BLA & $*$ & 10.4 & 9.6 & 9.0 & 11.7 & 5.2 & 7.8 \\
\hline KON & 66.9 & $*$ & 12.7 & 10.6 & 13.4 & 6.4 & 12.1 \\
\hline KRI & 66.9 & 68.0 & $*$ & 4.6 & 6.7 & 1.9 & 7.0 \\
\hline PER & 65.7 & 67.4 & 57.3 & $*$ & 9.9 & 7.5 & 10.2 \\
\hline PRU & 70.8 & 69.9 & 63.4 & 67.4 & $*$ & 5.6 & 11.2 \\
\hline SAT & 64.9 & 61.4 & 51.5 & 66.4 & 65.4 & $*$ & 5.0 \\
\hline SIP & 63.6 & 74.1 & 68.1 & 69.9 & 70.7 & 67.6 & $*$ \\
\hline
\end{tabular}

Similarities between site chronologies were high. All site chronologies crossdated well, except between SAT and KRI and PER and KRI (Table 4). Average values of $t_{B P}$ and GLK\% coefficients for combinations of site pairs were 8.5 and 66.1, respectively. The highest value was found between PRU and KON (13.4) and the lowest between KRI and SAT (1.9). All GLK\% coefficients were high, with the exception of the above-mentioned combinations with a low $t_{B P}$ value. The KRI site did not crossdate well with PER and SAT, but did match well with BLA (9.6) and KON (12.7). Residual site chronologies are presented in Figure 4.
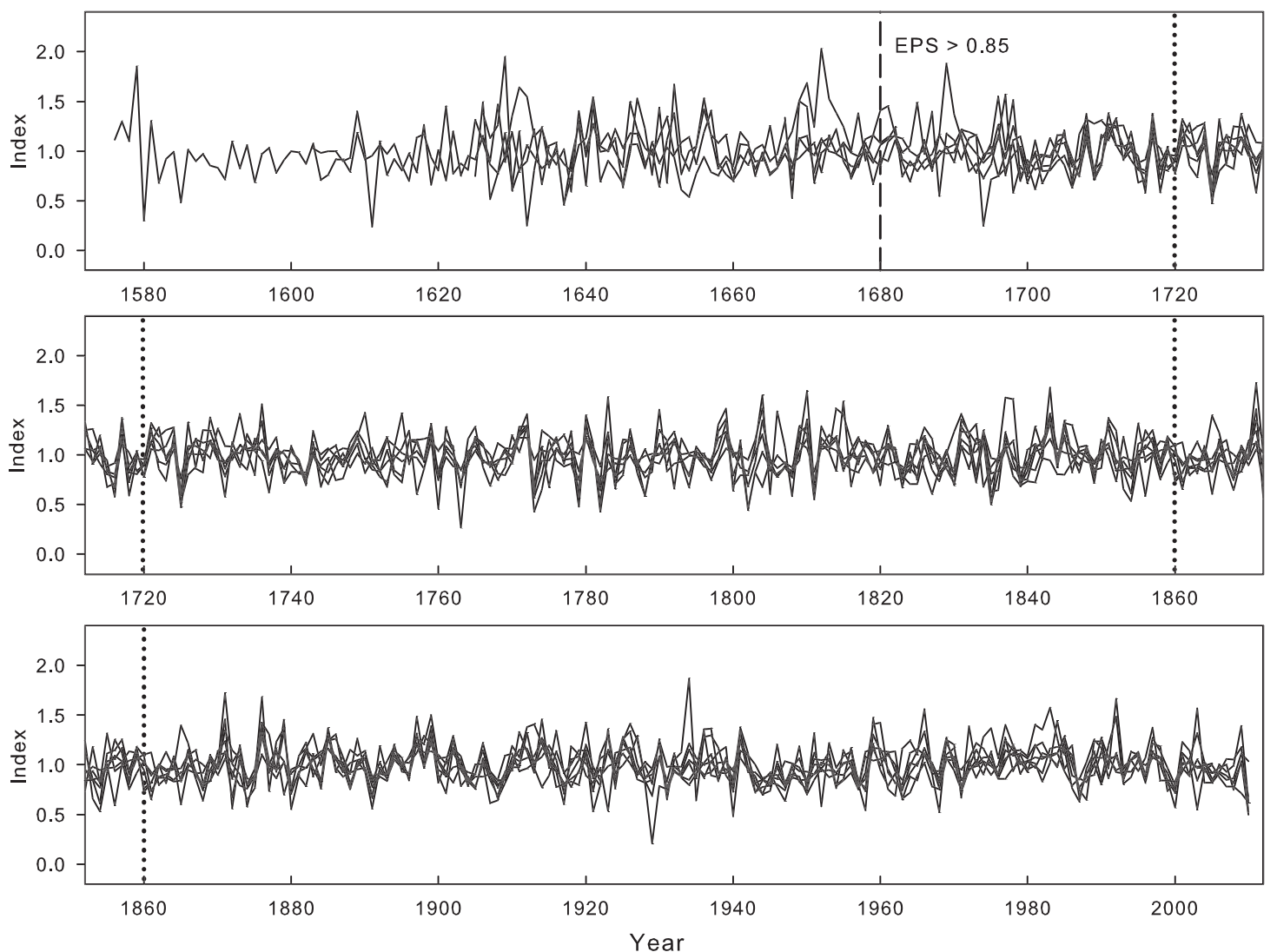

Figure 4. Residual chronologies for P. nigra from seven locations in $\mathrm{BiH}$. The dashed line represents the point on the chronology where the EPS value exceeds 0.85 , vertical dotted lines show connections between parts of the figure. 


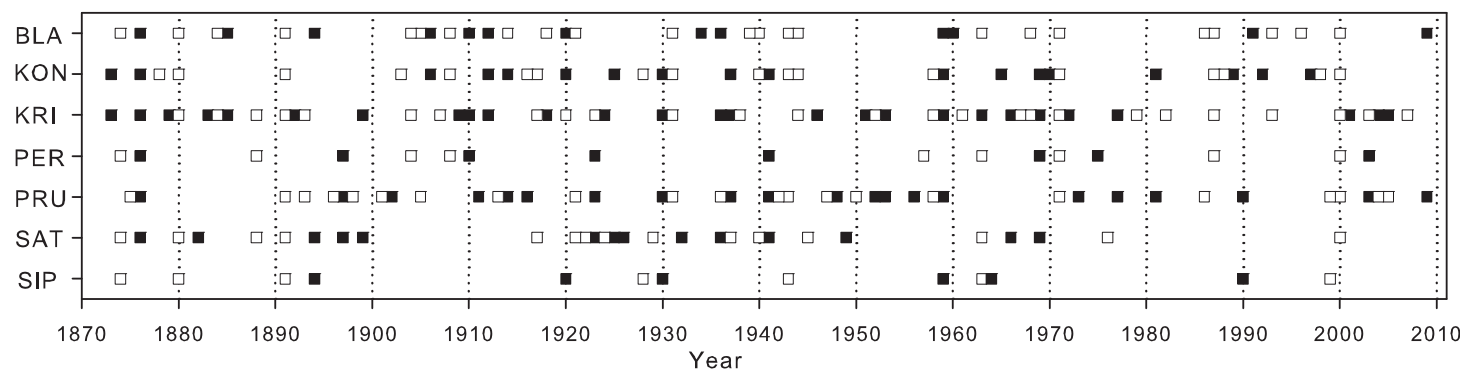

Figure 5. Pointer years at all 7 locations ( $\square$ represents a positive pointer year and $\square$ a negative). Scale of the $x$-axis is set to the common period 1873-2009 with sufficient sample depth on all seven sites.

\section{Pointer Years}

Pointer years (PYs) were studied at all seven locations. Altogether we found 287 positive and 308 negative PYs (Figure 5). We identified five positive $(1876,1930,1941,1959,1969)$ and nine negative $(1874,1880,1891,1931,1943,1963,1971$, 1987, 2000) PYs common to at least four out of seven sites.

Out of 14 positive PYs published in Hughes et al. (2001), two were present in at least four of our sites $(1930,1959)$, while three positive PYs $(1897,1910,1936)$ were found at three of our sites. Negative PYs seemed to be more local and had less similarity with those published, because only one year (1928) in Hughes et al. (2001) was found to be common to two of our sites.

\section{Regional Chronology for $\boldsymbol{P}$. nigra in Bosnia and Herzegovina}

A regional chronology for $P$. nigra was compiled from all seven site chronologies. All site chronologies crossdated well with the regional chronology, with $t_{\mathrm{BP}}$ values being equal or greater than 7.8 and GLK\% values being equal or greater than 65.7 (Table 5). The highest $t_{B P}$ value was found between the regional chronology and the site chronology KON (17.7), and the highest GLK\% coefficient was found between the regional chronology and the site chronology PRU (74.0).

Analyses of raw chronologies, included in the calculation of the regional chronology, confirmed the extreme growth conditions at all seven sites. The average tree-ring width was $0.87 \mathrm{~mm}$, but more than half of all tree rings were narrower than $0.77 \mathrm{~mm}$. Seventy-five percent of all tree rings were less than $1.04 \mathrm{~mm}$ wide. The narrowest ring was $0.11 \mathrm{~mm}$ and the widest $4.29 \mathrm{~mm}$. The widest TRW were found in juvenile period of the trees (above $1 \mathrm{~mm}$ ), but with increasing age the average TRW fell under $0.80 \mathrm{~mm}$; the raw chronology is presented in Figure 6a and the residual chronology in Figure 6b, while sample depth is presented in Figure 6c. After AD 1666, the sample depth exceeded 20 trees. Fifty trees included in the chronology were present after 1706, and after 1833, 100 trees were included. The highest number of trees covers the period from 1875 until the present, with more than 110 trees.

Table 5. Comparison of $\mathrm{BiH}$ regional P. nigra chronology with site chronologies (the respective chronology was temporarily removed from the regional chronology prior to comparison).

\begin{tabular}{lccccc}
\hline Site Chronologies & Start Year & End Year & Overlap & t $_{\text {BP }}$ & GLK\% \\
\hline BLA & 1624 & 2010 & 386 & 13.0 & 68.8 \\
KON & 1625 & 2010 & 385 & 17.7 & 73.6 \\
KRI & 1666 & 2010 & 344 & 9.4 & 65.7 \\
PER & 1602 & 2010 & 408 & 13.3 & 71.4 \\
PRU & 1693 & 2010 & 19.4 & 74.0 \\
SAT & 1812 & 2010 & 430 & 13.3 & 68.9 \\
SIP & 1575 & 2005 & & 73.8 \\
\hline
\end{tabular}



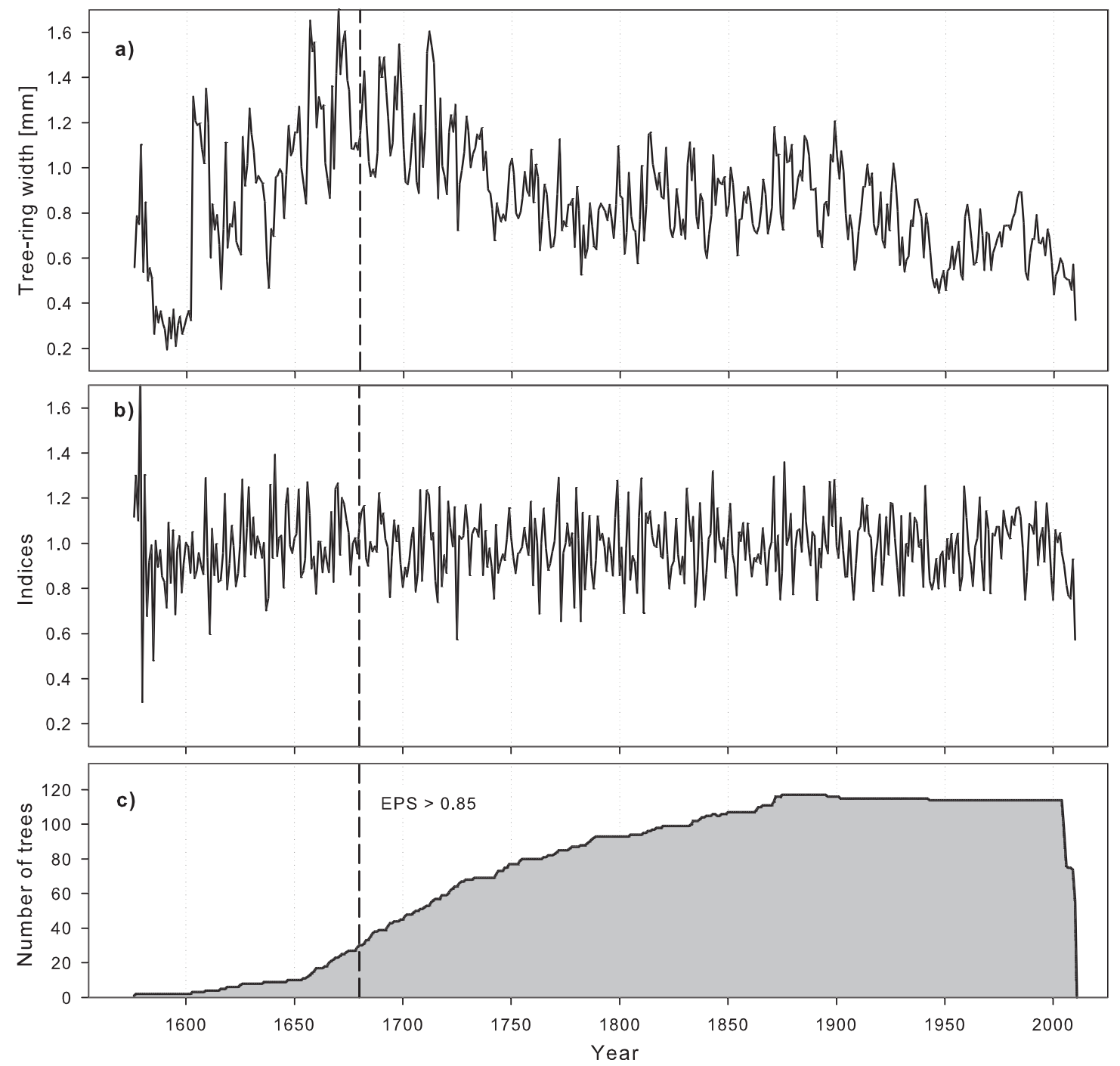

Figure 6. P. nigra regional raw (a) and residual chronology (b) with sample depth (c) for Bosnia and Herzegovina. The dashed line represents the point on the chronology where the EPS value exceeds 0.85 .

Comparisons with Other $\boldsymbol{P}$. nigra Chronologies from the Broader Region

The $\mathrm{BiH}$ regional $P$. nigra chronology was compared with other regional $P$. nigra chronologies for Southern Europe (Mediterranean area), Austria, and Switzerland, available in the TreeRing Data Bank or acquired through exchange with other laboratories. The highest $t_{B P}$ and GLK\% coefficients were found between the $\mathrm{BiH}$ and Montenegro chronologies (13.5 and 71.1, respectively) - Table 6 . Both parameters were also high when comparing the $\mathrm{BiH}$ chronology with chronologies from Albania, Austria, France, and Greece, ranging between 6.0 and 7.8 for $t_{B P}$ and 52.0 and 69.1 for GLK\%. We found a minor connection or no connection at all between the $\mathrm{BiH}$ chronology and chronologies from Slovenia, Switzerland, Turkey, Cyprus, and Spain. 
Table 6. Comparison of $\mathrm{BiH}$ regional P. nigra chronology to other regional chronologies.

\begin{tabular}{lccccc}
\hline \multicolumn{1}{c}{ Chronologies } & & & Overlap with BiH & \\
& Chronology & t $_{\text {BP }}$ & GLK\% \\
\hline Albania (Levanič and Toromani 2010) & 1769 & 2007 & 238 & 7.8 & 69.1 \\
Austria, regional chronology (Grabner, personal & & & & \\
$\quad$ communication) & 1318 & 1996 & 430 & 7.5 & 64.4 \\
Cyprus (Touchan and Hughes 2007) & 1553 & 2002 & 427 & 1.4 & 52.0 \\
France, Corsica (Schweingruber 1996b) & 1517 & 1980 & 405 & 6.0 & 58.8 \\
Greece, Langada (Schweingruber 1996c) & 1825 & 1981 & 156 & 2.4 & 60.8 \\
Greece, Zagradeniye (Huges et al. 2001) & 1706 & 1979 & 274 & 7.2 & 63.7 \\
Greece, Scotida (Kuniholm and Riches 2004) & 1751 & 2003 & 253 & 6.8 & 65.0 \\
Greece, Taygetos (Kuniholm and Groneman 2005) & 1657 & 1999 & 343 & 4.9 & 57.1 \\
Italy, Sicily (Schweingruber 1996d) & 1772 & 1980 & 208 & 4.2 & 57.2 \\
Montenegro (Levanič, preliminary results) & 1593 & 2006 & 414 & 13.5 & 71.1 \\
Slovenia (Levanič, preliminary results) & 1798 & 2008 & 210 & 4.1 & 62.1 \\
Spain (Fuster 1996) & 1686 & 1989 & 303 & 0.0 & 51.0 \\
Switzerland (Hobi 2008) & 1892 & 2007 & 115 & 2.3 & 59.6 \\
Turkey (Touchan et al. 2005) & 1770 & 2002 & 232 & 2.3 & 55.8 \\
\hline
\end{tabular}

\section{DISCUSSION}

We present the first 435-year-long regional chronology for P. nigra for Bosnia and Herzegovina. It was compiled from seven site chronologies originating from different substrates, elevations, and slopes, evenly dispersed across the country. The regional chronology has a sufficient sample depth and an EPS $>0.85$ from AD 1675 until the present. It is as long as $P$. nigra chronologies from nearby regions such as Cyprus, Corsica, and Montenegro (Schweingruber 1996b; Touchan and Hughes 2007; Levanič unpublished) and in some cases even longer than chronologies for Slovenia (unpublished data), Switzerland, Greece, and Albania (Schweingruber 1996c; Hobi 2008; Levanič and Toromani 2010). The length of the $\mathrm{BiH}$ regional chronology is close to the maximum age of P. nigra of ca. 500 years (Brus 2004). With the additional coring of dead wood or the collection of wood samples from old houses, it might be possible to construct an even longer $P$. nigra chronology, as was the case with the $P$. cembra chronology by Popa and Kern (2009) or with the oak and pine chronologies by Kuniholm and Striker (1983). In the latter case, the length of living tree chronologies was extended with oak and pine samples from churches, mosques, and houses, but the length of the $P$. nigra chronology from Duboka (Serbia) is only 342 years long and has not yet been extended (Kuniholm and Striker 1983).
The BiH regional $P$. nigra chronology correlates well with other $P$. nigra regional chronologies from the Balkan Peninsula or surrounding regions. The highest value of $t_{\mathrm{BP}}, 13.5$, found between $\mathrm{BiH}$ and Montenegro is not surprising because the chronologies from Montenegro are located ca. $50 \mathrm{~km}$ ESE from the PER in BiH. High values were also observed with the Albanian (7.8) and Austrian (7.5) P. nigra chronologies. These results indicate the existence of a north-south transect and will be used to develop a $P$. nigra dendrochronological network for the Balkan Peninsula.

Comparing the $\mathrm{BiH}$ regional $P$. nigra chronology with those from Cyprus, Spain, Italy, and Slovenia shows very few similarities. Although this was expected for the chronologies from Cyprus, Spain, and Italy because of the longer distances to these sites and different environmental conditions, it was surprising for the chronology from Slovenia particularly, because sites used to build the Slovenian P. nigra chronology are located between sites in $\mathrm{BiH}$ and Austria. This calls for further sampling on extreme sites in Slovenia, Croatia and northern $\mathrm{BiH}$ to connect the $\mathrm{BiH}$ regional chronology with that from Slovenia.

The small number of common PYs between our study and the study by Hughes et al. (2001) is not unexpected as the distance between the majority of sites is large. Moreover, there are a 
variety of other environmental factors (e.g. elevation, topographic features, edaphic conditions) that may account for differences among these sites.

The potential of the $\mathrm{BiH}$ P. nigra chronology for dendroclimatological studies has not yet been tested. However, sufficient sample depth, high $t_{B P}$ values between site chronologies, a large number of common pointer years, and high EPS values suggest that there must be a common signal in the tree rings. Similar research in Albania on the climate sensitivity of $P$. heldreichii (Seim et al. 2010) and P. nigra (Levanič and Toromani 2010) confirms that Pinus has a high potential for dendroclimatology in the region. Additionally, the newly constructed chronology for $\mathrm{BiH}$ could be used to date wooden artifacts, such as houses and religious objects or icons, from different parts of the country.

\section{ACKNOWLEDGMENTS}

We express our thanks to the forestry personnel from the Bosansko Grahovo, Konjuh, Konjic, Prusačka Rijeka, Šipovo, and Konjic forestry districts and to the rangers from Perucica National Park. This work was supported by the Slovenian Research Agency through the program and research group "Forest, biology, ecology and technology" P4-0107 and a doctoral study grant from Simon Poljanšek. We are also thankful to the Federal Hydrometeorological Institute of Bosnia and Herzegovina for supplying us with the meteorological data used in this study. We are grateful to Dr. Michael Grabner, BOKU Vienna, Austria for providing us Austrian regional P.nigra chronology.

\section{REFERENCES}

Accetto, M., 1979. Regeneration, growth and development of natural stands of Austrian Pine (Pinus nigra Arnold) on dolomite - limestone sites of Western Bosnia. Research Reports Forestry and Wood Technology. no. 17.

Allen, C. D., A. K. Macalady, H. Chenchouni, D. Bachelet, N. McDowell, M. Vennetier, T. Kitzberger, A. Rigling, D. D. Breshears, E. H. Hogg, P. Gonzalez, R. Fensham, Z. Zhang, J. Castro, N. Demidova, J.-H. Lim, G. Allard, S. W. Running, A. Semerci, and N. Cobb, 2010. A global overview of drought and heat-induced tree mortality reveals emerging climate change risks for forests. Forest Ecology and Management 259(4):660-684.

Auer, I., R. Böhm, A. Jurkovic, W. Lipa, A. Orlik, R. Potzmann, W. Schöner, M. Ungersböck, C. Matulla, K. Briffa, P. Jones, D. Efthymiadis, M. Brunetti, T. Nanni, M. Maugeri, L. Mercalli, O. Mestre, J.-M. Moisselin, M. Begert, G. Müller-Westermeier, V. Kveton, O. Bochnicek, P. Stastny, M. Lapin, S. Szalai, T. Szentimrey, T. Cegnar, M. Dolinar, M. Gajic-Capka, K. Zaninovic, Z. Majstorovic, and E. Nieplova, 2007. HISTALP-historical instrumental climatological surface time series of the Greater Alpine Region. International Journal of Climatology 27(1):17-46.

Baillie, M. G. L., and J. R. Pilcher, 1973. A simple cross-dating program for tree-ring research. Tree-Ring Bulletin 33:7-14.

Briffa, K. R., and P. D. Jones, 1990. Basic chronology statistics and assessment. In Methods of Dendrochronology: Applications in the Environmental Sciences, edited by E. R. Cook, and L. A. Kairiukstis, pp. 137-152. Kluwer academic publishers, Dordrecht, Boston, London.

Brus, R., 2004. Drevesne Vrste na Slovenskem (Tree species on Slovenian area; in Slovenian). Mladinska založba, Ljubljana.

Bussotti, F., 2002. Seed dispersal in pines. In Ecology and biogegraphy of Pinus, edited by D. M. Richardson, pp. 281-293. C.A.B. International, CABI Publishing, Cambridge.

Cook, E. R., 1985. Time Series Analysis Approach to Tree Ring Standardization. Ph.D. dissertation, University of Arizona, Laboratory of Tree-Ring Research, Tucson.

Cook, E. R., and K. R. Briffa, 1990. A comparison of some tree-ring standardization methods. In Methods of Dendrochronology: Applications in the Environmental Sciences, edited by E. R. Cook, and L. A. Kairiukstis, pp. 153-162. Kluwer Academic Publishers, Dordrecht, Boston, London.

Cook, E. R., and R. L. Holmes, 1999. Program ARSTAN chronology development with statistical analysis (users manual for program ARSTAN). Laboratory of Tree-Ring Research, University of Arizona, 18.

Cook, E. R., K. Briffa, S. Shiyatov, and V. Mazepa, 1990. Treering standardization and growth trend estimation. In Methods of Dendrochronology: Applications in the Environmental Sciences, edited by E. R. Cook, and L. A. Kairiukstis, pp. 104-162. Kluwer Academic Publishers, Dordrecht, Boston, London.

Eastwood, W. J., 2004. East Mediterranean vegetation and climate change. In Balkan Biodiversity: Pattern and process in the European hotspot, edited by H. I. Griffiths, B. Krystufek, and J. M. Reed, pp. 25-48. Kluwer, Dordrecht.

Eckstein, D., and J. Bauch, 1969. Beitrag zur Rationalisierung eines dendrochronologischen Verfahrens und zur Analyse seiner Aussagesicherheit. Forstwissenschaftliches Centralblatt 88(4):230-250.

Fritts, H. C., 1976. Tree Rings and Climate. Academic Press, London, New York, San Francisco.

Fuster, M. G., 1996. Pinus nigra - Andrinal, Spain (noaa-tree3283), National Climatic Data Center, NESDIS, NOAA, US Department of Commerce.

Gibson, D. C., R. Sisse, and S. Dug, 2003. Bosnia and Herzegovina - biodivesity assessment. USAID/Bosnia and Herzegovina, 74. 
Hobi, M. L., 2008. Wachstumsreaktionen von Buche, Waldföhre und Schwarzföhre auf einen Waldbrand. Master thesis, ETH Zurich, Departement für Umweltwissenschaften UWIS.

Holmes, R. L., 1983. Computer-assisted quality control in tree-ring dating and measurement. Tree-Ring Bulletin 43: 69-78.

Hughes, M. K., P. I. Kuniholm, J. K. Eischeid, G. Garfin, C. B. Griggs, and C. Latini, 2001. Aegean tree-ring signature years explained. Tree-Ring Research 57(1):67-73.

Isajev, V., B. Fady, H. Semerci, and V. Andonovski, 2004. EUFORGEN Technical Guidelines for genetic conservation and use for European black pine (Pinus nigra). International Plant Genetic Resource Institute, 6.

Kuniholm, P. I., 1981. Pinus nigra - Ravno Borje, Bosnia and Hercegovina (noaa-tree-3810), National Climatic Data Center, NESDIS, NOAA, US Department of Commerce.

Kuniholm, P. I., and C. L. Striker, 1983. Dendrochronological Investigations in the Aegean and Neighboring Regions, 1977-1982. Journal of Field Archaeology 10(4):411-420.

Kuniholm, P. I., and N. Riches, 2004. Pinus nigra - Scotida forest Kastoria, Greece (noaa-tree-3813), National Climatic Data Center, NESDIS, NOAA, US Department of Commerce.

Kuniholm, P. I., and C. Groneman, 2005. Pinus nigra - Taygetos forest, Greece (noaa-tree-3814), National Climatic Data Center, NESDIS, NOAA, US Department of Commerce.

Leal, S., D. Eamus, M. Grabner, R. Wimmer, and P. Cherubini, 2008. Tree rings of Pinus nigra from the Vienna basin region (Austria) show evidence of change in climatic sensitivity in the late 20th century. Canadian Journal of Forest Research 38(4):744-759.

Levanič, T., 2007. ATRICS - A new system for image acquisition in dendrochronology. Tree-Ring Research 63(2): 117-122.

Levanič, T., and E. Toromani, 2010. Austrian pine (Pinus nigra Arnold.) tree-ring width chronology from northeast Albaniapreliminary results. In TRACE - Tree rings in Archaeology, Climatology and Ecology, pp. 104-109. Otočec, Slovenija, Helmholtz -Zentrum Potsdam, Deutsches Geoforschungszentrum.

Linares, J. C., and P. A. Tíscar, 2010. Climate change impacts and vulnerability of the southern populations of Pinus nigra subsp. salzmannii. Tree Physiology 30(7):795-806.

Martinelli, N., 2004. Climate from dendrochronology: Latest developments and results. Global and Planetary Change 40: 129-139.

Pachauri, R. K., and A. Reisinger, Editors. IPCC, 2007: Climate Change 2007: Synthesis Report, Contribution of Working Groups I, II and III to the Fourth Assessment Report of the Intergovernmental Panel on Climate Change. Geneva, Switzerland: IPCC; 2007; 104 pp.

Panayotov, M., P. Bebi, V. Trouet, and S. Yurukov, 2010. Climate signal in tree-ring chronologies of Pinus peuce and Pinus heldreichii; from the Pirin Mountains in Bulgaria. Trees - Structure and Function 24(3):479-490.

Pintarić, K., 1999. Forestry and Forest Reserves in Bosnia and Herzegovina. In Virgin Forests and Forest Reserves in Central and East European Countries: History, Present Status and Future Development, edited by J. Diaci, pp. 1-15. Department of Forestry and Renewable Forest Resources, Biotechnical faculty, University of Ljubljana, Ljubljana.

Popa, I., and Z. Kern, 2009. Long-term summer temperature reconstruction inferred from tree-ring records from the Eastern Carpathians. Climate Dynamics 32(7):1107-1117.

Proctor, J., and S. R. J. Woodell, 1975. The ecology of serpentine soils. Advances in Ecological Research 9:255-365.

Schweingruber, F. H., 1996a. Picea abies - Jahorina and Vlašič, Bosnia and Hercegovina (noaa-tree-4724), National Climatic Data Center, NESDIS, NOAA, US Department of Commerce.

Schweingruber, F. H., 1996b. Pinus nigra - Col de Sorba, Mount Renoso, France (noaa-tree-4389), National Climatic Data Center, NESDIS, NOAA, US Department of Commerce.

Schweingruber, F. H., 1996c. Pinus nigra - Langada (Sparta), Greece (noaa-tree-4500), National Climatic Data Center, NESDIS, NOAA, US Department of Commerce.

Schweingruber, F. H., 1996d. Pinus nigra - Aetna Linguaglossa, Italia (noaa-tree-4304), National Climatic Data Center, NESDIS, NOAA, US Department of Commerce.

Schweingruber, F. H., D. Eckstein, F. Serre-Bachet, and O. U. Bräker, 1990. Identification, presentation and interpretation of event years and pointer years in dendrochronology. Dendrochronologia 8:9-38.

Seim, A., K. Treydte, U. Büntgen, J. Esper, P. Fonti, H. Haska, F. Herzig, W. Tegel, and D. Faust, 2010. Exploring the potential of Pinus heldreichii Christ. for long-term climate reconstruction in Albania. In TRACE - Tree rings in Archaeology, Climatology and Ecology, Otočec, pp. 75-82. Slovenija, Helmholtz-Zentrum Potsdam, Deutsches Geoforschungszentrum.

Sevgi, O., and U. Akkemik, 2007. A dendroecological study on Pinus nigra Arn. at different altitudes of northern slopes of Kazdaglari, Turkey. Journal Of Environmental Biology/ Academy Of Environmental Biology, India 28(1):73-75.

Stevanović, V., K. Tan, and G. Iatrou, 2003. Distribution of the endemic Balkan flora on serpentine I. - obligate serpentine endemics. Plant Systematics and Evolution 242(1):149-170.

Stokes, M. A., and T. L. Smiley, 1996. An Introduction to TreeRing Dating. The University of Arizona Press, Tucson.

Strumia, G., R. Wimmer, and M. Grabner, 1997. Dendroclimatic sensitivity of Pinus nigra Arnold in Austria. Dendrochronologia 15:129-137.

Touchan, R., and M. K. Hughes, 1999. Dendrochronology in Jordan. Journal of Arid Environments 42(4):291-303.

Touchan, R., and M. K. Hughes, 2007. Pinus nigra Armiantos, Cyprus (noaa-tree-5546), National Climatic Data Center, NESDIS, NOAA, US Department of Commerce.

Touchan, R., D. M. Meko, and A. Aloui, 2008. Precipitation reconstruction for northwestern Tunisia from tree rings. Journal of Arid Environments 72(10):1887-1896.

Touchan, R., G. Funkhouser, M. Hughes, and N. Erkan, 2005a. Standardized Precipitation Index reconstructed from Turkish tree-ring widths. Climatic Change 72(3):339-353.

Touchan, R., Ü. Akkemik, M. K. Hughes, and N. Erkan, 2007. May-June precipitation reconstruction of southwestern Anatolia, Turkey during the last 900 years from tree rings. Quaternary Research 68(2):196-202. 
Touchan, R., E. Xoplaki, G. Funkhouser, J. Luterbacher, M. K. Hughes, N. Erkan, Ü. Akkemik, and J. Stephan, 2005b. Reconstructions of spring/summer precipitation for the Eastern Mediterranean from tree-ring widths and its connection to large-scale atmospheric circulation. Climate Dynamics 25(1):75-98.

Vidaković, M., 1991. Conifers: Morphology and Variation. Grafički zavod Hrvatske, Zagreb.
Wigley, T. M. L., K. R. Briffa, and P. D. Jones, 1984. On the average value of correlated time series, with applications in dendroclimatology and hydrometeorology. Journal of Climate and Applied Meteorology 23:201-213.

Received 10 May 2011; accepted 15 October 2011. 